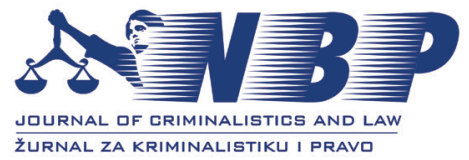

NBP 2021, Vol. 26, Issue 1, pp. 35-59

doi:10.5937/nabepo26-29443

Original scientific paper

\title{
Private Security Preparedness for Disasters Caused by Fire
}

\author{
${ }^{1}$ Vladimir Cvetković, ${ }^{2}$ Slavica Pavlović, ${ }^{3}$ Bojan D. Janković1 \\ ${ }^{1}$ University of Belgrade, Faculty of Security Studies, Belgrade, Serbia \\ ${ }^{2}$ Scientific-Professional Society for Disaster Risk Management, Belgrade, Serbia \\ ${ }^{3}$ University of Criminal Investigation and Police Studies, Belgrade, Serbia
}

Submitted: 2020-11-17 • Accepted: 2021-05-05 • Published: 2021-05-10

\begin{abstract}
The subject of the research was the examination of the factors of influence on the preparedness of the private security for disasters caused by fire. In addition to determining the preparedness index, there are deeper insights into the interrelationships between various selected variables and the level of preparedness of members of the private security. Using the random sampling method, 300 adult members of the private security were selected, and they participated in the research. The results of the research indicate that members of private security were not sufficiently prepared to react to fires. The research results could be used as a starting point for conducting further research in this area since the improvement in training of security personnel plays an important role in disaster control and prevention, thereby producing safer and more secure work environment and society.
\end{abstract}

Keywords: security, factors of influence, members, private security, fires.

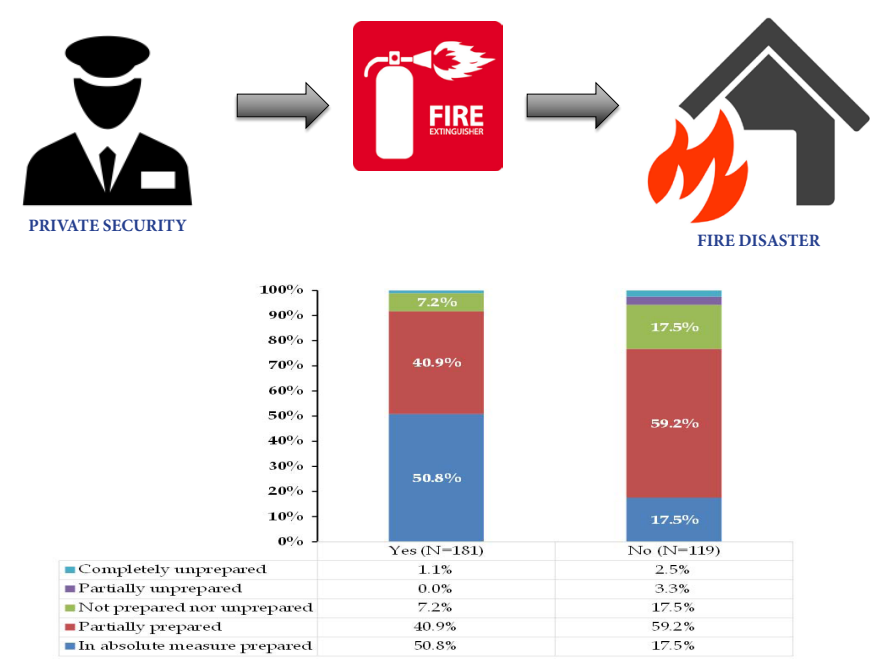

$\overline{1 \text { Corresponding }}$ author: bojan.jankovic@kpu.edu.rs 


\section{INTRODUCTION}

Any deviation from the regular course of life has a negative impact on the economic, cultural, political, and social capital of a community and requires an adequate response in the form of special protection measures by persons specially trained to deal with disasters (Al-ramlawi et al., 2020; Busch \& Givens, 2013; Kaur, 2020; Menković et al., 2018). Appropriate implementation of special protection measures is especially emphasized in fires because they occur more often than other disasters (Cvetković, 2016a; Cvetković, 2016b; Dwyer et al., 2000; Marshall et al., 1998). As a frequent and serious threat to the safety of people and their property (Gulaid et al., 1988; Mallonee et al., 1996), fire is a process of uncontrolled combustion of combustible matter, the occurrence of which requires the presence of combustible matter, presence of oxygen, an energy source, and mutual influence of these elements (Cvetković \& Gačić, 2017). Timely and proper reaction in the initial phase of a fire can affect the prevention of fires that may have huge consequences (Gulaid et al., 1988; Martell, 2015). This is the reason why it is advisable for a person designated as the "first responder", often a member of the private security, to acquire certain knowledge and skills to be able to respond to a disaster caused by fire (Bojičić, 2013; Milojević et al., 2015).

Various events and the burden on the state system have imposed the need to engage the private security industry (Craighead, 2009; Edwards \& Heiduk, 2015). The measures and tasks entrusted to members of private security depend on the type of engagement, which can be preventive or repressive. When repressive measures occur, it is a sign that an emergency has occurred and caused disasters for the tasks of the security service (Milošević, 2006). In the event of a fire, it is necessary to follow the steps provided by the procedure for dealing with fires. In case of small fires, it is necessary to start extinguishing using adequate means. In any other case, support, i.e., engagement of experts is obligatory. Of course, for a person to participate in firefighting, it is necessary to have adequate training and knowledge in this area, because otherwise, such a person can endanger both himself and the others (Hignett et al., 2015; Milen, 2009; Useem et al., 2005; Cvetković \& Filipović, 2018). By respecting the prescribed standards and norms, there is an adequate distance provided between the facilities which would prevent the spread of fire, sufficient water for firefighting and access roads that also allow easier access to facilities and efficient evacuation of vulnerable persons (Raković \& Jakovljević, 2011).

To mitigate the risk of negative consequences of disasters, various preventive measures are applied (Cvetković et al., 2020; Gulaid et al., 1988; Hussaini, 2020), which can be grouped as structural and non-structural measures (Cvetković, 2016a; Cvetković, 2016b). Structural measures include all construction, mechanical, electrical measures that prevent the occurrence of fire spreading. Non-structural measures imply the acquisition of appropriate knowledge and implementation of certain training to respond efficiently and promptly (Goyal, 2019). In the literature, several papers are examining the level of preparedness to respond to fire disasters (De Wit \& Helsloot, 2021; Knuth et al., 2017; Steen-Hansen et al., 2021; Sund \& Jaldell, 2018; Cvetković \& Filipović, 2018; Cvetković \& Gačić, 2017; Cvetković et al., 2018; Khan, 2008; Ku- 
mar \& Newport, 2007; Mumović \& Cvetković, 2019; Olawuni et al., 2020; Ozmen, 2006). For the purposes of this paper, fire preparedness shall mean the following: appropriate knowledge of combustion processes, ways of extinguishing fires, preventive measures; written or oral response plans in such situations; evacuation plan; fire alarm and extinguishing devices (Kihila, 2017; Mahoney et al., 2005; Rohrmann, 1995; Sturtevant \& McCaffrey, 2006; Cvetković \& Filipović, 2018). The researchers' attention was also drawn to the issue of preparedness of members of emergency rescue services and other services of the private security sector to determine the degree of their preparedness for efficient work performance (Aleksandrina et al., 2019; Cvetković \& Janković, 2020; Janković \& Cvetković, 2020; Kumiko \& Shaw, 2019; Öcal et al., 2020; Vraćević \& Cvetković, 2019; Xuesong \& Kapucu, 2019).

Given that it is concluded that no government has the ability and knowledge to provide adequate security to its citizens, hence the need for private security companies to complement the state's efforts (Chinwokwu, 2018). Security activities are a permanent system of measures and procedures that, according to a certain plan, are undertaken by authorized services or individuals together with and in cooperation with other related services to protect the object of security measures (Isenberg, 2009). Therefore, the term security and protection of persons means a set of measures, actions, and procedures that ensure their integrity and uninterrupted performance of functions (Schulz \& Yeung, 2008). Nowadays, there is more and more unplanned construction of various facilities, which usually do not meet the conditions of adequate fire protection. The consequences caused by this approach are not taken into account until they occur (Raković \& Jakovljević, 2011). According to Cvetković and Filipović (2018), the level of awareness of citizens about fires, their occurrence, and possible consequences play a significant role in taking preventive measures to prevent fire outbreaks.

The review of various scientific papers directly or indirectly related to the actions of officials in the event of disasters (Busch \& Givens, 2013; Chinwokwu, 2018; Cvetkovic, 2019; Janković et al., 2019) has revealed that there is the compliance in the ability of security service to act in disasters, but also that not enough attention and research has been paid to this topic. Regarding to that, the aim of this paper is scientific explanation of the private security preparedness for disasters caused by fire. In accordance with the above, the presumed goal of the research refers to the scientific description of the index of preparedness of the private security members for reacting to fires.

\section{METHOD}

The subject of the research is a comprehensive examination of the nature of preparedness of the private security members to respond to disasters caused by fires (Figure 1). In addition to determining the preparedness index, there are deeper insights into the interrelationships between the various selected variables and the level of preparedness itself. 


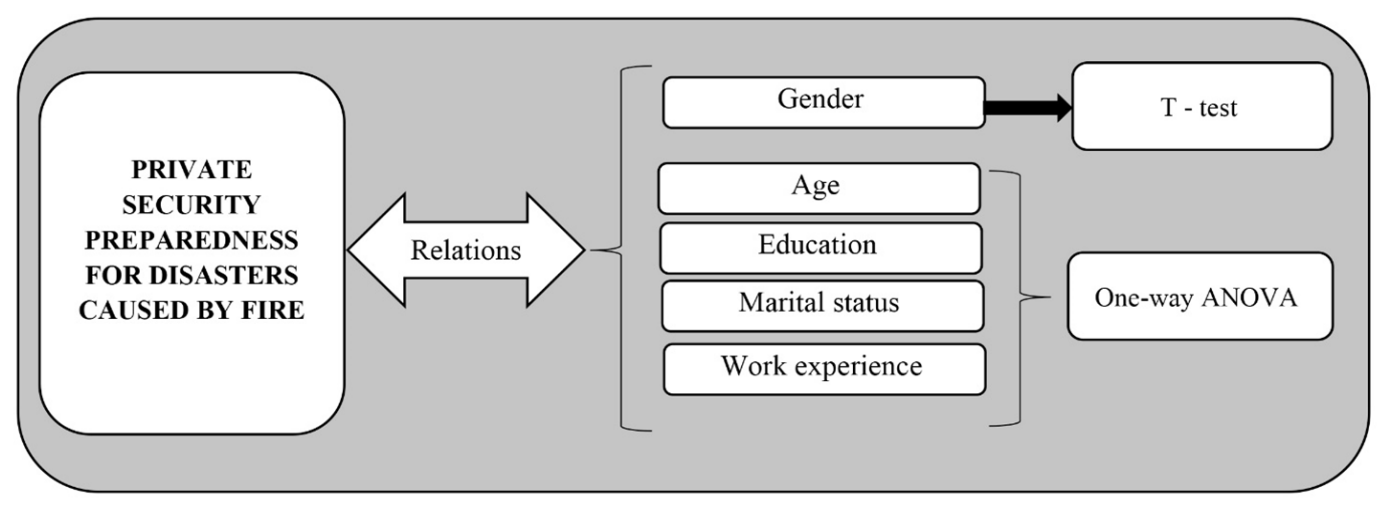

Figure 1. Research design

\section{Sample}

In the research process, the members of private security currently at work in all three shifts participated. There were 300 respondents who participated in the research and they were selected by the method of random sampling. Demographic and socio-economic characteristics of the sample are shown in Table 1.

Table 1. Sample structure $(N=300)$

\begin{tabular}{lccc}
\hline Variable & Category & N & $\%$ \\
\hline \multirow{2}{*}{ Gender } & Male & 266 & 88.7 \\
& Female & 34 & 11.3 \\
Age & $18-41$ & 63 & 21.1 \\
& $41-60$ & 163 & 54.5 \\
\multirow{4}{*}{ Education } & Over 60 & 73 & 24.4 \\
& Secondary school & 273 & 79.8 \\
& High school & 31 & 10.4 \\
& Faculty & 29 & 9.8 \\
Marital status & Single & 53 & 17.7 \\
& In a relationship & 33 & 11 \\
& Engaged & 6 & 2 \\
& Married & 166 & 55.3 \\
& Divorced & 30 & 10 \\
& Widow/widower & 12 & 4 \\
Work experience & Up to 5 years & 131 & 43.7 \\
& 5-10 years & 89 & 29.7 \\
& More than 10 & 80 & 26.7 \\
\hline
\end{tabular}




\section{Questionnaire design}

The research was conducted using a survey method with a structured survey questionnaire which was developed by analysing several studies examining fire preparedness (Gandit et al., 2009; Lambert et al., 2021; Merino et al., 2006; Runefors et al., 2021; Slovic, 1987; Taylor \& Daniel, 1984; Xin \& Huang, 2013). The structured questionnaire was developed using close-ended and five-point Likert scale questions (1 [strongly disagree] to 5 [strongly agree]) (see Appendix). The first part of the questionnaire contained the socio-economic and demographic characteristics of respondents and the second sections included questions related:

- Whether security officers, as a category of employees most often entrusted with fire protection, are familiar with the procedures and action plans in case of fire and how they would react in case of activation of the fire alarm;

- Whether the members of the private security have had the opportunity to use a fire extinguisher and put out the fire, and what kind of fire they would put out with a fire extinguisher;

- Whether evacuation exercises have been conducted and whether these exercises have had any impact on the sense of personal preparedness;

- Whether years of experience affect the assessment of the risk of fire in the workplace in the following 5 years;

- Whether the professional exam in fire protection passed also means that the person believes he has the necessary knowledge for the proper use of fire extinguishers;

- Whether they had the opportunity to use a fire extinguisher and extinguish a fire in their workplace, and which fire they would extinguish with a fire extinguisher;

- Whether the previous experience in fire extinguishing and using fire extinguishers influenced the assessment of which fire can be extinguished with a fire extinguisher and etc.

To determine the importance of education, special attention is drawn to the question of whether the completed professional exam in the field of fire protection contributes to better possession of knowledge for the proper use of fire extinguishers.

\section{Statistical analysis}

Descriptive statistics were calculated for the basic socio-economic and demographic characteristics of the participants. The data obtained using the survey questionnaire underwent adequate preparation: editing, coding, and statistical adjustment. Descriptive and inferential statistical analyses were performed using SPSS Statistics (IBM SPSS Statistics, Version 26, New York, NY, USA). The data were presented in tables, while a one-factor analysis of ANOVA variance was used to examine the relationship between demographic and socio-economic variables. In order to examine the relationship between the mentioned dependent variables and certain independent variables, one-way ANOVA was used to determine the influence of age, marital status, and level of education of citizens on dependent continuous variables on the preparedness of security officers to act in case of fire emergencies. The homogeneity 
of the variances was examined using a test for each of the mentioned groups. Based on the results of Levene's test, the assumption of homogeneity of variance of different variables was violated and accordingly the results of the Robust Tests of Equality of Means were given, as well as of two tests, the Welch and Brown-Forsythe versions that do not assume the equality of variance. For examining our research questions, the results of the Welch test were used. To examine the interrelationship between the gender of respondents and certain continuous dependent variables, expressed in the form of subscales of preparedness, education, and risk perception, the independent samples T-test was chosen. Our research was consistent with the Helsinki Declaration outlining the principles for socio-medical research involving human subjects. Additionally, participants provided informed consent to participate in the study. The research protocol was approved by the committees of the scientific research group review board of the Scientific-Professional Society for Disaster Risk Management and International Institute for Disaster Research, ID-05012021.

\section{RESULTS}

Starting from the first question "Have you ever participated in extinguishing the fire?", $68.3 \%$ respondents answered in the affirmative, while $31.7 \%$ answered in the negative. To the question: "Do you think that there is a risk of fire in your workplace?" $86 \%$ answered that there was, while $14 \%$ believed that there was not. About $97.5 \%$ of respondents answered the question "Is there a fire extinguisher in your workplace?" and the majority of respondents $94.3 \%$ point out that there were fire extinguishers at their workplace. When asked, "Did you have the opportunity to use a fire extinguisher?" there were as many as $76.67 \%$ respondents who stated that they did, while $23.33 \%$ respondents did not use a fire extinguisher at all. Out of all the respondents who used the fire extinguisher, $97.3 \%$ respondents stated that they were familiar with the proper use of the fire extinguisher.

When fire-extinguishing systems are in question, 53\% respondents have used the hydrant network in their work so far, while $57 \%$ of them have not used it yet. About $46.67 \%$ respondents became familiar with the sprinkler system, while $53.33 \%$ of them did not have the opportunity to work with it. To the two key questions, namely "Are you familiar with the combustion processes?" and "Are you familiar with the methods of extinguishing fire?" $80.7 \%$ of the respondents answered that they are familiar with the combustion processes, while $87.3 \%$ of respondents are familiar with the methods of extinguishing fires. A large number of respondents (86.7\%) answered in the affirmative to the question "Are you aware of the preventive measures that have been taken at your workplace?" while 13.3\% said they were not familiar. 


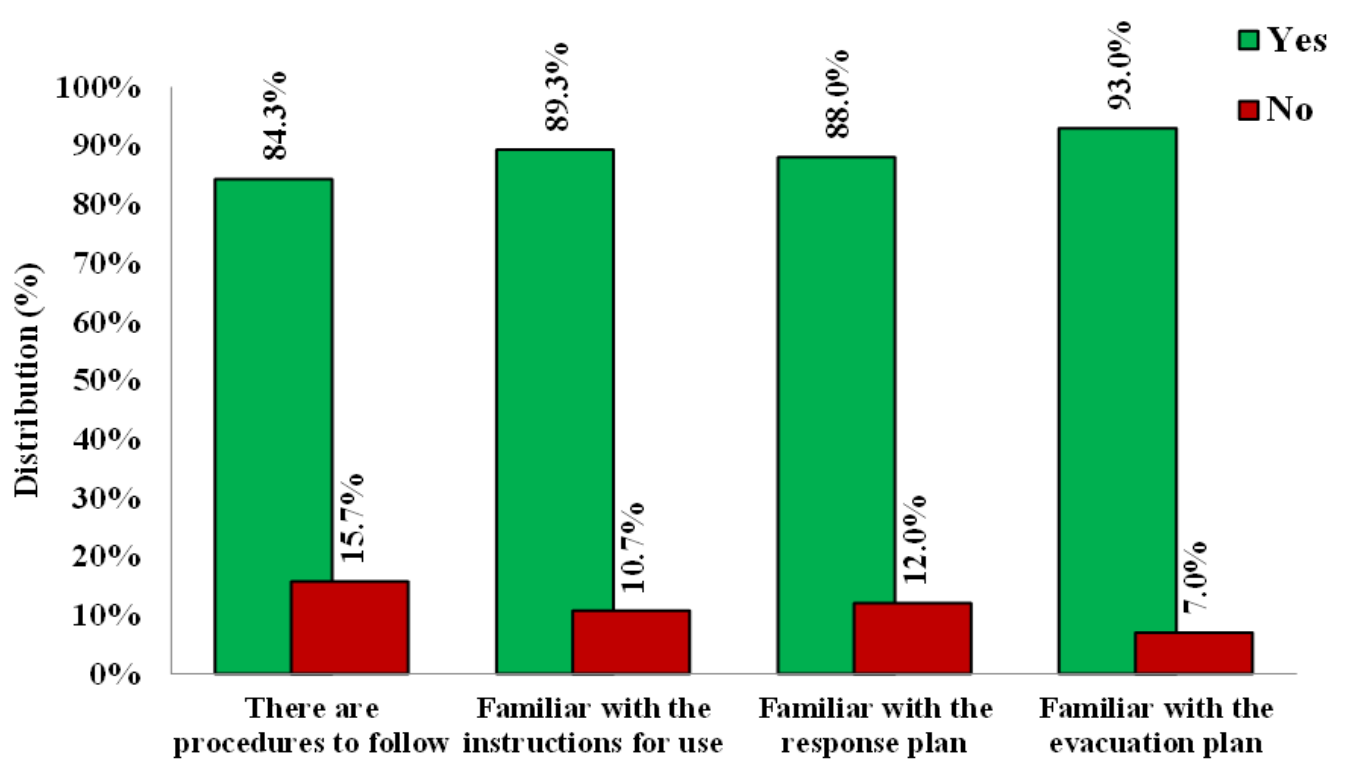

Figure 2. Respondents' answers regarding knowledge of fire response procedures

When asked, "Are there emergency procedures in your workplace?" $84.33 \%$ the respondents confirmed that there were such procedures, while $15.67 \%$ stated there were none. When asked, "Are you familiar with the guidelines on how to act in case of activation of the fire alarm?" about $89.33 \%$ respondents stated that they were familiar, while $10.67 \%$ answered in the negative. Also, $88 \%$ respondents answered in the affirmative to the question "Are you familiar with the fire emergency action plan?" while $12 \%$ stated that they were not familiar with it. Out of all respondents, 93\% answered that they were familiar with the fire emergency evacuation plan, while $7 \%$ respondents answered that they were not familiar with it (Figure 2).

When asked, "Are the fire emergency evacuation exercises being carried out at your workplace?" $60.3 \%$ of respondents answered that they are, while $39.7 \%$ stated that they are not carried out. More than half of the respondents $53.7 \%$ believe that the facility they are working at is fully prepared to deal with emergencies, while only $1 \%$ of respondents believe that the facility is completely unprepared. When assessing their individual preparedness, a very small number of respondents believe that they are unprepared for various disasters (3\%), while the vast majority believes that they are prepared for them.

With respect to assessing the preparedness of their colleagues, only nine respondents consider their colleagues unprepared to deal with disasters. On the other hand, estimating the fire risk and probability of its occurrence in the following 5 years, $59.5 \%$ of respondents believe that a fire will certainly not happen or will not happen in their workplace, $9.9 \%$ have no opinion on this issue (Figure 3). 


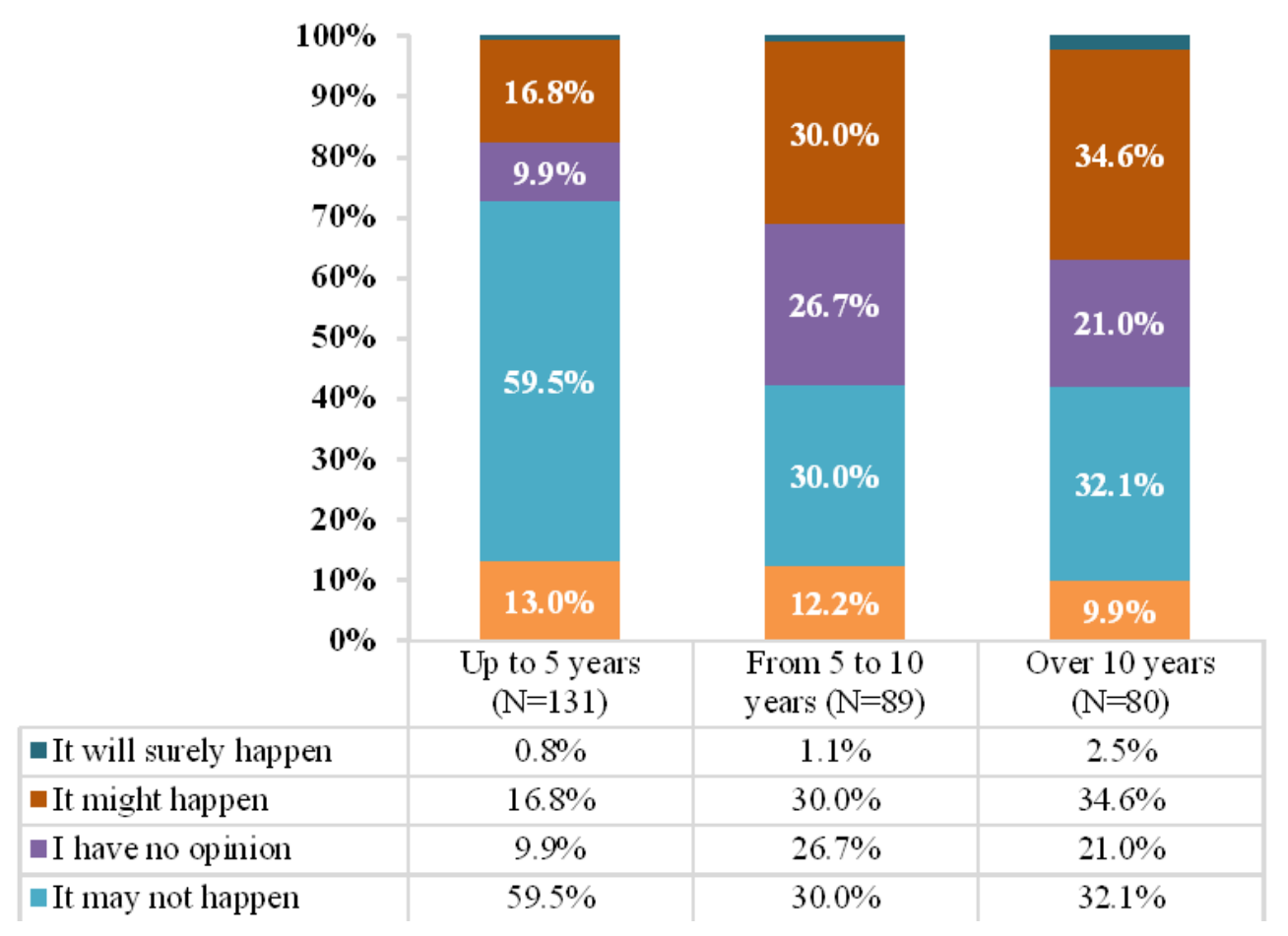

Figure 3. Respondents' answers regarding probability of fire occurrence according to years of work experience

About 56\% mentioned material consequences as the most probable ones, while $24.3 \%$ mentioned the loss of life, $19.3 \%$ listed the occurrence of injuries, while only one respondent recognized environmental consequences as the most probable one. To the question "In your opinion, what is the correct procedure in case of activation the fire alarm control panel?", the majority of respondents, 251 out of 300 , said that they would approach the control panel and read the information on it, $7.7 \%$ think that the fire fighters should be called immediately (Table 2).

Table 2. Respondents' answers regarding the correct procedure in case of activation of the fire alarm control panel

\begin{tabular}{lcc}
\hline Procedure & Frequency & $\%$ \\
\hline Leave the workplace & 3 & 1 \\
Wait for the alarm to go off & 9 & 3 \\
Read the information on the control panel & 251 & 83.7 \\
The fire department is called immediately & 23 & 7.7 \\
$\begin{array}{l}\text { The head of the security department is } \\
\text { called }\end{array}$ & 14 & 4.7 \\
Total & 300 & 100 \\
\hline
\end{tabular}


When asked to specify the legal period for retesting fire extinguishers was, $70.3 \%$ of respondents answered that retesting was done after 6 months, 18\% of respondents believed that fire extinguishers were retested after 9 months, $8.7 \%$ thought that it was done after 12 months, $2.3 \%$ of respondents believed it was done after 3 months, while $0.7 \%$ thought that the devices were not retested.

A total of 293 respondents answered that the telephone number of the fire service was 193 (the correct answer), five respondents answered that the number of the fire service was 192, 1 respondent answered that the number of the fire service was 194 and 1 respondent answered that it was 112. In the process of extinguishing the fire, the person in charge of fire protection must know how each fire should be extinguished. When asked to specify the type of fire that can be extinguished with a fire extinguisher the majority of respondents $(77.7 \%)$ answered that only fire in the initial stage can be extinguished. About $81.3 \%$ of respondents would put out the fire on electrical installations with powder, while $8.7 \%$ of respondents were not sure which tool to use (Table 3).

Table 3. Respondents' answers regarding firefighting in electrical installations

\begin{tabular}{lcc}
\hline Choice & Frequency & $\%$ \\
\hline Powder & 244 & 81.3 \\
Foam & 17 & 5.7 \\
Water & 3 & 1 \\
Sand & 10 & 3.3 \\
I am not sure & 26 & 8.7 \\
Total & 300 & 100 \\
\hline
\end{tabular}

Analysing the importance of education, the respondents were asked whether they attended safety and health at work training when entering employment. Out of 300 respondents, 288 confirmed that they attended the mentioned training, while 12 of them stated that they did not. In terms of holding licenses, most members of the private security are licensed to perform the basic duties of unarmed security officers (Table 4). 
Table 4. Overview of license holders - members of the private security

\begin{tabular}{|c|c|c|c|}
\hline License & Answer & $\begin{array}{l}\text { Frequen- } \\
\quad \text { cy }\end{array}$ & $\%$ \\
\hline \multirow{2}{*}{$\begin{array}{l}\text { License for risk assessment in the } \\
\text { protection of persons, property } \\
\text { and business }\end{array}$} & Yes & 104 & 34.7 \\
\hline & No & 196 & 65.3 \\
\hline \multirow{2}{*}{$\begin{array}{l}\text { License for performing basic duties } \\
\text { of a security officer - without weapons }\end{array}$} & Yes & 227 & 75.7 \\
\hline & No & 73 & 24.3 \\
\hline \multirow{2}{*}{$\begin{array}{l}\text { License for performing specialist tasks } \\
\text { of security officers - with weapons }\end{array}$} & Yes & 101 & 33.7 \\
\hline & No & 199 & 66.3 \\
\hline \multirow{2}{*}{$\begin{array}{l}\text { License for performing technical } \\
\text { protection system planning activities }\end{array}$} & Yes & 51 & 17 \\
\hline & No & 249 & 83 \\
\hline \multirow{2}{*}{$\begin{array}{l}\text { License for technical protection } \\
\text { activities }\end{array}$} & Yes & 50 & 16.7 \\
\hline & No & 250 & 83.3 \\
\hline \multirow{2}{*}{$\begin{array}{l}\text { Certificate of passing the professional } \\
\text { exam in the field of fire protection }\end{array}$} & Yes & 205 & 68.3 \\
\hline & No & 95 & 31.7 \\
\hline
\end{tabular}

Out of a total of 181 respondents who participated in the evacuation exercises, 166 respondents rated their preparedness as "fully or partially prepared", 13 respondents rated themselves as "neither prepared nor unprepared", while two respondents rated themselves as "completely unprepared". Out of a total of 119 respondents who did not participate in the evacuation exercises, 92 respondents rated themselves as "fully or partially prepared", 18 respondents rated themselves as "neither prepared nor unprepared", while 9 respondents declared that they were "partially or completely unprepared" (Figure 4).

Using the T-test, a statistically significant difference between the mean values of the observed variables in men and women was investigated. Before using the test, we examined the general and special preconditions for its implementation. The obtained research results show that there is a statistically significant difference $(\mathrm{p}<0.001)$ in results between men and women in terms of the subscale of education. Women (mean difference $=1.62$, standard deviation $=0.17$ ) are more widely educated and with licenses necessary to work than men (mean difference $=1.49$, standard deviation $=0.21$ ). 


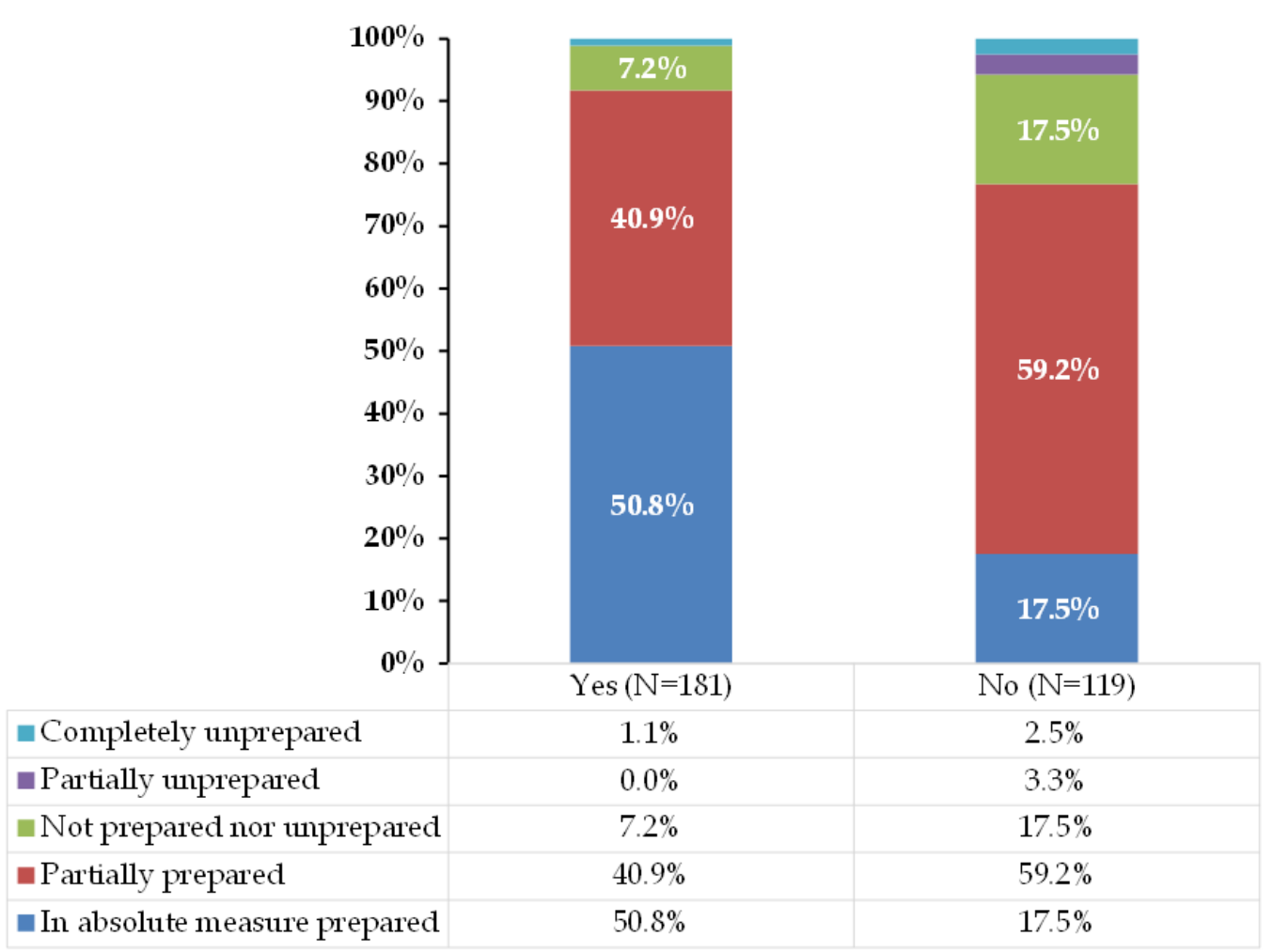

Figure 4. Percentage distribution of attitudes regarding the assessment of personal preparedness in relation to the conducted evacuation exercises

One-way ANOVA results show that there is a statistically significant difference between the mean values of these groups in risk perception (Table 5). Further analyses show that respondents aged 30-50 (mean difference $=2.74$, standard deviation $=$ 1.06) perceive risks to a greater extent if compared to respondents aged 18-30 (mean difference $=2.52$, standard deviation $=1.04$ ). In addition, the impact of education and the subscale of education, preparedness and risk perception were examined. The obtained results show that there is no statistically significant difference between the mean values of these groups in the subscales of education, preparedness, and risk perception.

Table 5. Results of one-factor analysis of variance (ANOVA) of different education groups and subscales of education, preparedness and risk perception $(N=300)$

\begin{tabular}{lcccccc}
\hline \multirow{2}{*}{ Variable } & \multicolumn{3}{c}{ Age } & \multicolumn{1}{c}{ Education } & \multicolumn{2}{c}{ Marital status } \\
\cline { 2 - 7 } & \multicolumn{7}{c}{.17} & .31 & 3.35 & .068 & 3.90 & $.022^{\star}$ \\
\hline Education subscale & 1.17 & .06 & 2.23 & .084 & 4.93 & $.008^{\star}$ \\
Preparedness subscale & 2.72 & .06 & & & & \\
Risk perception subscale & 4.18 & $.017^{\star}$ & 0.52 & .093 & 8.64 & $.000^{* *}$ \\
\hline
\end{tabular}

Note: $* p \leq .05 ; * * p \leq .01$ 
The obtained results show that there is a statistically significant difference between the mean values of marital status in the subscale of education, preparedness, and risk perception. Further analyses show that respondents who are not married (mean difference $=1.51$, standard deviation $=0.22$ ) invest more in their education and promoted to perform private security activities if compared with the respondents who are married (mean difference $=1.47$, standard deviation $=0.21$ ). Further analyses also found that non-married respondents (mean difference $=1.27$, standard deviation $=0.28$ ) rated their level of preparedness higher than married respondents (mean difference $=1.27$, standard deviation $=0.28$ ), which is directly conditioned by the previous results. Finally, it was found that the respondents who are not married (mean difference $=2.76$, standard deviation $=1.04$ ) assess the risks of fire emergency in the company as more probable one than the respondents who are married (mean difference $=2.33$, standard deviation $=0.93$ ).

\section{DISCUSSION}

The obtained research results show that slightly more than half of the respondents participated in firefighting and that they have some kind of experience in such situations. Such results may indicate that fires are very common in the workplace or that experiences have been gained through various trainings, which is consistent with the results of previous research (Nilson \& Bonander, 2020; Stumpf et al., 2017).

However, the question arises as to whether the way of reacting in such situations was appropriate and timely. In addition, the majority of respondents believe that there is a risk of fire in the workplace, which largely indicates the need and importance of education and training of employees for safe and proper response. An encouraging circumstance is the fact that most of the respondents stated that there are fire extinguishers in the workplace. Certainly, it has not been determined whether these devices are correct and whether all employees would know how to use them in disasters caused by fires. The results show that more than $70 \%$ had the opportunity to use the mentioned devices, which still does not indicate whether they were used properly. Although the results obtained are consistent with previous research (Chien \& Wu, 2008; Warda \& Ballesteros, 2008; Xin \& Huang, 2014), in the future research, it is necessary to determine the extent to which employees are trained for their proper and safe use. Also, the results showed that slightly more than a half of the respondents had experience with the hydrant network, but it was not determined how they used it and whether it was done in a proper and safe way (Coar et al., 2020).

The fact is that the fire cannot be absolutely prevented, but by taking various preventive measures, establishing regular inspection processes, regular servicing and maintenance of fire protection systems, correct and regular updating of procedures, instructions and other internal acts, which provide fire protection, it is possible to reduce consequences in case of fire (Crosby, 1905; Daane \& Toth, 2005; Diamantes \& Jones, 2020; Fan et al., 2020; Fuller, 1991; Mallonee et al., 1996; Zamarreño-Aramendia et al., 2020). Therefore, it is extremely important that the person entrusted with fire protection is informed about the measures and steps taken in case of fire 
protection. The obtained results showed that only a small number of respondents (one tenth) are not familiar with fire protection measures in the workplace and the largest number of respondents point out that there are defined procedures for dealing with fires. Such research results are consistent with the results of numerous studies conducted around the world (Hapgood et al., 2000; Kendrick, 1994; Mulvaney \& Kendrick, 2004). In practice, the question arises as to whether this is a reflection of the real situation or the desire to present the situation in a much better perspective than it really is. Employee testing is needed to determine objective knowledge of such procedures in practice.

Certainly, it is important to point out that the respondents largely emphasize that they know the processes of burning and extinguishing, while on the other hand, it should be emphasized that their knowledge about it has not been tested, but it is a subjective assessment. Certainly, the obtained research results are in accordance with the previously conducted research (Istre et al., 2002; Kumar \& Rao, 1995; Metallinou, 2020). At the same time, it was determined that the respondents were slightly more familiar with the method of extinguishing fires in relation to the knowledge of the combustion process. Preparedness for the worst case scenario is a basic precondition for improving resilience, and regular exercises and simulations play a significant role in this process (Kendrick, 1994; Kendrick et al., 2013). However, almost half of the respondents clearly indicated that evacuation exercises and trainings are not carried out in the workplace. This can be a serious safety issue given all the undeniable benefits of such exercises (Kinateder et al., 2014; Murphy \& Foot, 2011; Silva et al., 2013; Zhao et al., 2009).

There is no relationship between education and subscales of education, preparedness and risk perception. The results of the research are not consistent with the results of previous research which emphasizes the importance of education in various aspects of fire preparedness (Rhodes, 2011; Rohrmann, 1995; Salmon, 2004). On the other hand, a statistically significant association was found between gender and the education subscale, which is consistent with some studies (Andrews et al., 2014) while not with others (Setyawan et al., 2021). In relation to age it was determined that such a link exists with the subscale of risk perception, while the marital status of such a connection exists with the subscale of education. Several studies have also found a connection between family structure and residential fires (Fahy \& Norton, 1989; Southwick \& Butler, 1985). Starting from the results that unmarried respondents invest more in their education, it can be assumed that they have more free time, financial resources and are more interested in their training. Such assumptions also explain the results according to which such a category of respondents to a greater extent assesses the level of their preparedness. However, the question arises as to what the decisive factors are that influence unmarried respondents in relation to the previously mentioned factors.

By taking various preventive measures, the consequences in the event of a fire can be reduced, which is why it is important that the person entrusted with fire protection is aware of the preventive measures. In order to achieve that, it is necessary for the person to undergo appropriate training and to improve continuously. The level of awareness of citizens about fires, their occurrence and possible consequences plays

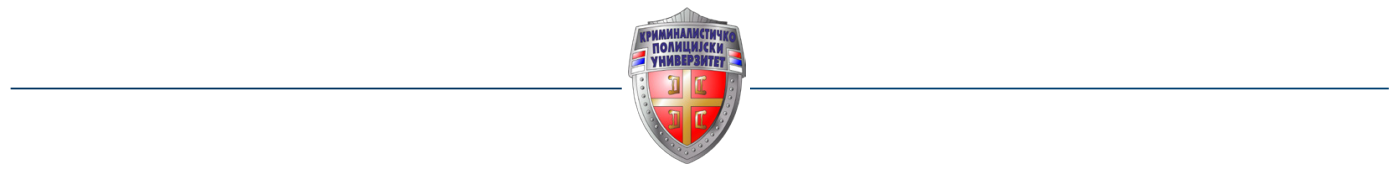


a major role in taking preventive measures to prevent such a fire (Cvetković \& Filipović, 2018). A survey conducted on the work and efficiency of the security service (Chinwokwu, 2018) showed that $78.6 \%$ of respondents confirm that security officers react quickly to disasters, while $21.4 \%$ of respondents disagree with that. In case of fires, the speed of reaction is a key factor in reducing the consequences. Given the fact that fire protection is usually entrusted to security officers, the ability to respond, preparedness and competencies required must be at a high level. The survey confirms that $71.6 \%$ of respondents believe that the security service has the ability to respond to calls in disasters (Chinwokwu, 2018). The research found that a very small number of respondents consider themselves unprepared for various catastrophes, and it is similar to the attitudes of respondents about the preparedness of their colleagues, who, according to their belief, are usually well prepared for disasters. This brings us to the question that could be explored further, whether security officers are overestimated in the eyes of others or whether security officers underestimate their ability and preparedness. The role of security officers in disaster conditions is poorly and insufficiently researched phenomenon, bearing in mind that the private security sector has a long history (Janković \& Cvetković, 2020; Janković et al., 2021). However, in recent years, more and more researchers have been attracted to this field of studies, which gives us hope that in the future this area will be researched more profoundly and published in scientific papers. Except in the field of science, it is necessary to increase awareness of the importance of protection and focus on reducing the large fluctuation of personnel within the private security activities. Reducing the fluctuation of security officers would directly affect the improvement of their readiness, because the training process would not only be repeated, but would also mean an upgrade of the acquired knowledge. For such an endeavour, it is necessary to increase the standards of employees in the private security industry. The continuous increase in the number and intensity of consequences caused by fires imposes the need for immediate improvement of the fire protection system on the territory of the Republic of Serbia (Cvetković, 2019). Security officers who very often appear in this role must be able to respond to the task and be prepared to act in the event of a large fire. That is why trainings, exercises, and various types of education are necessary in order for the officer to prepare for the potential situation and thus influence the fire protection, and the direct reduction of consequences (Xin \& Huang, 2013). Fires are unpredictable, and each fire has its own characteristics, but taking exercises can reduce panic and create the sense of confidence in security officers to justify the trust placed in them (Istre et al., 2002).

The conducted research also has its limitations, which are reflected in the subjective assessment of the respondents in terms of many aspects of the research without objective testing that would be even more realistic; insufficient interest of the respondents for the most objective assessment of the situation on the ground; management pressures to better present the situation on the ground, etc. 


\section{CONCLUSION}

Starting from the subject of research, the paper identifies numerous results that largely represent the current situation in terms of private security preparedness for disasters caused by fire. It was found that certain factors greatly affect the level of preparedness, while on the other hand some factors do not have such an impact. Certainly, the level of preparedness that was determined after the research indicates a sufficient level of knowledge of security procedures and how to react in such situations. However, it is necessary to improve the legislation that would further accelerate the implementation of trainings and exercises that raise the level of operability of members of such services. In future research, it is necessary to conduct tests in order to assess the real situation on the ground in the most impartial and objective way in terms of knowledge, risk perception and preparedness for such situations.

\section{REFERENCES}

Aleksandrina, M., Budiarti, D., Yu, Z., Pasha, F., \& Shaw, R. (2019). Governmental incentivization for SMEs' engagement in disaster resilience in Southeast Asia. International Journal of Disaster Risk Management, 1(1), 32-50. http://dx.doi. org/10.18485/ijdrm.2019.1.1.2

Al-ramlawi, A. H., El-Mougher, M. M., \& Al-Agha, M. R. (2020). The role of Al-Shifa Medical Complex administration in evacuation \& sheltering planning. International Journal of Disaster Risk Management, 2(2), 19-36. https://doi.org/10.18485/ ijdrm.2020.2.2.2

Andrews, R., Ashworth, R., \& Meier, K. J. (2014). Representative bureaucracy and fire service performance. International Public Management Journal, 17(1), 1-24. http://dx.doi.org/10.1080/10967494.2014.874253

Bojičić, N. (2013). Funding of the protection and rescue system in the Republic of Serbia. NBP. Nauka, bezbednost, policija, 18(1), 129-143.

Busch, N. E., \& Givens, A. D. (2013). Achieving resilience in disaster management: The role of public-private partnerships. Journal of Strategic Security, 6(2), 1-19. http://dx.doi.org/10.5038/1944-0472.6.2.1

Chien, S.-W., \& Wu, G.-Y. (2008). The strategies of fire prevention on residential fire in Taipei. Fire Safety Journal, 43(1), 71-76. https://doi.org/10.1016/j.firesaf.2007.04.004

Chinwokwu, E. C. (2018). An assessment of the relationship between private security companies and the police in crime prevention in Lagos Metropolis, Nigeria. International Journal of Police Science \& Management, 20(1), 80-93. https://doi. org/10.1177/2F1461355718756413 
Coar, M., Garlock, M., \& Elhami Khorasani, N. (2020). Effects of water network dependency on the electric network for post-earthquake fire suppression. Sustainable and Resilient Infrastructure, 5(5), 269-288. https://doi.org/10.1080/23789689.2018. 1563408

Craighead, G. (2009). High-rise security and fire life safety. Butterworth-Heinemann.

Crosby, E. U. (1905). Fire prevention. The Annals of the American Academy of Political and Social Science, 26(2), 224-238.

Cvetković, V. M. (2016a). Influence of employment status on citizen preparedness for response to natural disasasters. NBP. Nauka, bezbednost, policija, 21(2), 46-95. http://dx.doi.org/10.5937/nbp1602049C

Cvetković, V. (2016b). Uticaj demografskih, socio-ekonomskih i psiholoških faktora na preduzimanje preventivnih mera. Kultura polisa, 13(32), 393-404.

Cvetkovic, V. M. (2019). Risk perception of building fires in Belgrade. International Journal of Disaster Risk Management, 1(1), 81-91. https://doi.org/10.18485/ ijdrm.2019.1.1.5

Cvetković, V., \& Filipović, M. (2018). Ispitivanje percepcije rizika o požarima u stambenim objektima: demografski i socio-ekonomski faktori uticaja. Vojno delo, 70(5), 82-98. https://doi.org/10.5937/vojdelo1805082C

Cvetković, V., \& Gačić, J. (2017). Fires as threatening security phenomenon: Factors of influence on knowledge about fires. In I. Nadj (Ed.), $10^{\text {th }}$ International scientific conference "Crisis management days": Book of papers (pp. 326-336). University of Applied Sciences.

Cvetković, V., \& Janković, B. (2020). Private security preparedness for disasters caused by natural and anthropogenic hazards. International Journal of Disaster Risk Management, 2(1), 23-33. https://doi.org/10.18485/ijdrm.2020.2.1.3

Cvetković, V., Giulia, R., Ocal, A., Filipović, M., Janković, B., \& Eric, N. (2018). Childrens and youths' knowledge on forest fires: Discrepancies between basic perceptions and reality. Vojno delo, 70(1), 171-185. https://doi.org/10.5937/vojdelo1801171C

Cvetković, V., Nikolić, N., Nenadić, R. U., Ocal, A., \& Zečević, M. (2020). Preparedness and preventive behaviors for a pandemic disaster caused by COVID-19 in Serbia. International Journal of Environmental Research and Public Health, 17(11), 4124. https://doi.org/10.3390/ijerph17114124

Daane, S. P., \& Toth, B. A. (2005). Fire in the operating room: principles and prevention. Plastic and reconstructive surgery, 115(5), 73e-75e. https://doi.org/10.1097/01. prs.0000157015.82342.21

De Wit, R. A. C., \& Helsloot, I. (2021). Public perception in regard to fire service in the Netherlands. 210416-008641. Fire Safety Journal, 122, 103343. https://doi. org/10.1016/j.firesaf.2021.103343

Diamantes, D., \& Jones Jr, A. M. (2020). Principles of fire prevention. Jones \& Bartlett Learning. 
Dwyer, E., Pinnock, S., Grégoire, J. M., \& Pereira, J. M. C. (2000). Global spatial and temporal distribution of vegetation fire as determined from satellite observations. International Journal of Remote Sensing, 21(6-7), 1289-1302. https://doi. org/10.1080/014311600210182

Edwards, S. A., \& Heiduk, F. (2015). Hazy days: Forest fires and the politics of environmental security in Indonesia. Journal of Current Southeast Asian Affairs, 34(3), 65-94. https://doi.org/10.1177\%2F186810341503400303

Fahy, R., \& Norton, A. (1989). How being poor affects fire risks. Fire Journal (Boston, MA), 83(1), 29-36.

Fan, Y.-J., Zhao, Y.-Y., Hu, X.-M., Wu, M.-Y., \& Xue, D. (2020). A novel fire prevention and control plastogel to inhibit spontaneous combustion of coal: Its characteristics and engineering applications. Fuel, 263, 116693. https://doi.org/10.1016/j. fuel.2019.116693

Fuller, M. (1991). Forest fires: An introduction to wildland fire behavior, management, firefighting, and prevention. John Wiley \& Sons.

Gandit, M., Kouabenan, D. R., \& Caroly, S. (2009). Road-tunnel fires: Risk perception and management strategies among users. Safety science, 47(1), 105-114. https:// doi.org/10.1016/j.ssci.2008.01.001

Goyal, N. (2019). Disaster governance and community resilience: The law and the role of SDMAs. International Journal of Disaster Risk Management, 1(2), 61-75. https://doi.org/10.18485/ijdrm.2019.1.2.5

Gulaid, J. A., Sattin, R. W., \& Waxweiler, R. J. (1988). Deaths from residential fires, 1978-1984. Morbidity and Mortality Weekly Report: Surveillance Summaries, 37(1), 39-45. https://www.jstor.org/stable/44784785

Hapgood, R., Kendrick, D., \& Marsh, P. (2000). How well do socio-demographic characteristics explain variation in childhood safety practices? Journal of Public Health, 22(3), 307-311. https://doi.org/10.1093/pubmed/22.3.307

Hignett, S., Wolf, L., Taylor, E., \& Griffiths, P. (2015). Firefighting to innovation: using human factors and ergonomics to tackle slip, trip, and fall risks in hospitals. Human factors, 57(7), 1195-1207. https://doi.org/10.1177\%2F0018720815593642

Hussaini, A. (2020). Environmental planning for disaster risk reduction at Kaduna International Airport, Kaduna, Nigeria. International Journal of Disaster Risk Management, 2(1), 35-49. https://doi.org/10.18485/ijdrm.2020.2.1.4

Isenberg, D. (2009). Private military contractors and US grand strategy. International Peace Research Institute (PRIO).

Istre, G. R., McCoy, M., Carlin, D. K., \& McClain, J. (2002). Residential fire related deaths and injuries among children: Fireplay, smoke alarms, and prevention. Injury Prevention, 8(2), 128-132. http://dx.doi.org/10.1136/ip.8.2.128

Janković, B., \& Cvetković, M. V. (2020). Public perception of police behaviors in the disaster COVID-19 - the Case of Serbia. Policing: An International Journal of 
Police Strategies and Management, 43(6), 979-992. https://doi.org/10.1108/PIJPSM-05-2020-0072

Janković, B., Cvetković, V. M., \& Ivanov, A. (2019). Perceptions of private security: A case of students from Serbia and North Macedonia. NBP. Nauka, bezbednost, policija, 24(3), 59-72. https://doi.org/10.5937/nabepo24-23302

Janković, B., Cvetković, V., Milojević, S., \& Ivanović, Z. (2021). Relations between police and private security officers: A case study of Serbia. Security Journal. https:// doi.org/10.1057/s41284-021-00289-z

Kaur, B. (2020). Disasters and exemplified vulnerabilities in a cramped public health infrastructure in India. International Journal of Disaster Risk Management, 2(1), 1522. https://doi.org/10.18485/ijdrm.2020.2.1.2

Kendrick, D. (1994). Children's safety in the home: parents' possession and perceptions of the importance of safety equipment. Public Health, 108(1), 21-25. https:// doi.org/10.1016/s0033-3506(05)80031-9

Kendrick, D., Young, B., Mason-Jones, A. J., Ilyas, N., Achana, F. A., Cooper, N. J., Hubbard, S. J., Sutton, A. J., Smith, S., \& Wynn, P. (2013). Home safety education and provision of safety equipment for injury prevention. Evidence-Based Child Health: A Cochrane Review Journal, 8(3), 761-939. https://doi.org/10.1002/ebch.1911

Khan, M. S. A. (2008). Disaster preparedness for sustainable development in Bangladesh. Disaster Prevention and Management: An International Journal, 17(5), 662671. http://dx.doi.org/10.1108/09653560810918667

Kihila, J. M. (2017). Fire disaster preparedness and situational analysis in higher learning institutions of Tanzania. Jàmbá: Journal of Disaster Risk Studies, 9(1), 1-9. http://dx.doi.org/10.4102/jamba.v9i1.311

Kinateder, M., Ronchi, E., Nilsson, D., Kobes, M., Müller, M., Pauli, P., \& Mühlberger, A. (2014, January). Virtual reality for fire evacuation research [Conference paper]. 1st Complex Events and Information Modelling at the Federated Conference on Computer Science and Information System, Warsaw, Poland. http://dx.doi. org/10.13140/2.1.3380.9284

Knuth, D., Schulz, S., Kietzmann, D., Stumpf, K., \& Schmidt, S. (2017). Better safe than sorry: Emergency knowledge and preparedness in the German population. Fire Safety Journal, 93, 98-101. https://doi.org/https://doi.org/10.1016/j.firesaf.2017.08.003

Kumar, S., \& Rao, C. V. S. K. (1995). Fire load in residential buildings. Building and Environment, 30(2), 299-305. https://doi.org/10.1016/0360-1323(94)00043-R

Kumar, T. A., \& Newport, J. K. (2007). Institutional preparedness and sustainability of micro finance institutions during post disaster scenario. Disaster Prevention Management: An International Journal, 16(1), 21-32. https://doi. org/10.1108/09653560710729785 
Kumiko, F., \& Shaw, R. (2019). Preparing international joint project: Use of Japanese flood hazard map in Bangladesh. International Journal of Disaster Risk Management, 1(1), 62-80. http://dx.doi.org/10.18485/ijdrm.2019.1.1.4

Lambert, K., Merci, B., Gryspeert, C., \& Jekovec, N. (2021). Search \& rescue operations during interior firefighting: A study into crawling speeds. Fire Safety Journal, 121, 103269. https://doi.org/https://doi.org/10.1016/j.firesaf.2020.103269

Mahoney, E. J., Harrington, D. T., Biffl, W. L., Metzger, J., Oka, T., \& Cioffi, W. G. (2005). Lessons learned from a nightclub fire: Institutional disaster preparedness. Journal of Trauma and Acute Care Surgery, 58(3), 487-491. https://doi. org/10.1097/01.ta.0000153939.17932.e7

Mallonee, S., Istre, G. R., Rosenberg, M., Reddish-Douglas, M., Jordan, F., Silverstein, P., \& Tunell, W. (1996). Surveillance and prevention of residential-fire injuries. New England Journal of Medicine, 335(1), 27-31. https://doi.org/10.1056/ nejm199607043350106

Marshall, S. W., Runyan, C. W., Bangdiwala, S. I., Linzer, M. A., Sacks, J. J., \& Butts, J. D. (1998). Fatal residential fires: Who dies and who survives? Jama, 279(20), 16331637. https://doi.org/10.1001/jama.279.20.1633

Martell, D. L. (2015). A review of recent forest and wildland fire management decision support systems research. Current Forestry Reports, 1(2), 128-137. https://doi. org/10.1007/s40725-015-0011-y

Menković, L., Košćal, M., Milivojević, M., \& Đokić, M. (2018). Morphostructure relations on the territory of the Republic of Serbia. Glasnik Srpskog geografskog društva, 98(2), 1-28. https://doi.org/10.2298/GSGD1802001M

Merino, L., Caballero, F., Martínez-de Dios, J. R., Ferruz, J., \& Ollero, A. (2006). A cooperative perception system for multiple UAVs: Application to automatic detection of forest fires. Journal of Field Robotics, 23(3-4), 165-184. https://doi.org/10.1002/ rob.20108

Metallinou, M.-M. (2020). Emergence of and learning processes in a civic group resuming prescribed burning in Norway. Sustainability, 12(14), 5668. https://doi. org/10.3390/su12145668

Milen, D. (2009). The ability of firefighting personnel to cope with stress. Journal of Social Change, 3(1), 38-56.

Milojević, S., Janković, B., \& Cvetković, V. (2015). Prediction model of effective studies at the Academy of Criminalistics and Police Studies. NBP. Nauka, bezbednost, policija, 20(1), 135-149. http://dx.doi.org/10.5937/NBP1501135M

Milošević, M. (2006). Fizičko-tehničko obezbeđenje i protivpožarna zaštita. Glosarijum.

Mulvaney, C., \& Kendrick, D. (2004). Engagement in safety practices to prevent home injuries in preschool children among white and non-white ethnic minority families. Injury Prevention, 10(6), 375-378. https://doi.org/10.1136/ip.2004.005397 
Mumović, N., \& Cvetković, V. M. (2019). Činioci uticaja na donošenje odluka o sprovođenju evakuacije u uslovima katastrofa izazvanih požarima u stambenim objektima - studija slučaja Beograda. Vojno delo, 71(7), 142-163. https://doi. org/10.5937/vojdelo1907142M

Murphy, G. R. F., \& Foot, C. (2011). ICU fire evacuation preparedness in London: A cross-sectional study. British Journal of Anaesthesia, 106(5), 695-698. https://doi. org/10.1093/bja/aer033

Nilson, F., \& Bonander, C. (2020). Household fire protection practices in relation to socio-demographic characteristics: Evidence from a Swedish national survey. Fire Technology, 56(3), 1077-1098. https://doi.org/10.1007/s10694-019-00921-w

Öcal, A., Cvetković, V. M., Baytiyeh, H., Tedim, F. M. S., \& Zečević, M. (2020). Public reactions to the disaster COVID-19: A comparative study in Italy, Lebanon, Portugal, and Serbia. Geomatics, Natural Hazards and Risk, 11(1), 1864-1885. https:// doi.org/10.1080/19475705.2020.1811405

Olawuni, P., Olowoporoku, O., \& Daramola, O. (2020). Determinants of residents' participation in disaster risk management in Lagos Metropolis Nigeria. International Journal of Disaster Risk Management, 2(2), 1-18. https://doi.org/10.18485/ ijdrm.2020.2.2.1

Ozmen, F. (2006). The level of preparedness of the schools for disasters from the aspect of the school principals. Disaster Prevention and Management: An International Journal, 15(3), 383-395. https://doi.org/10.1108/09653560610669873

Raković, J., \& Jakovljević, V. (2011). Prostorno i urbanističko planiranje u funkciji zaštite od požara u urbanim sredinama [Spatial and urban planning in the function of fire protection in urban areas]. Godišnjak Fakulteta bezbednosti, 227-239.

Rhodes, A. (2011). Opinion: ready or not?: Can community education increase householder preparedness for bushfire? Australian Journal of Emergency Management, 26(2), 6-10.

Rohrmann, B. (1995). Effective risk communication for fire preparedness: A conceptual framework. Australian Journal of Emergency Management, 10(3), 42-46.

Runefors, M., Jonsson, A., \& Bonander, C. (2021). Factors contributing to survival and evacuation in residential fires involving older adults in Sweden. Fire Safety Journal, 122, 103354. https://doi.org/https://doi.org/10.1016/j.firesaf.2021.103354

Salmon, L. (2004). Fire in the OR - Prevention and preparedness. AORN Journal, 80(1), 41-54. https://doi.org/https://doi.org/10.1016/S0001-2092(06)60842-9

Schulz, S., \& Yeung, C. (2008). Private military and security companies and gender. DCAF. 
Setyawan, H., Nugraheni, A. M., Haryati, S., Qadrijati, I., Fajariani, R., Wardani, T. L., Atmojo, T. B., \& Sjarifah, I. (2021). The correlation of fire knowledge toward disasters response and preparedness practice among hospital nurse Klaten Central Java, Indonesia. IOP Conf. Ser.: Earth Environ. Sci., 724, 01204. https://iopscience. iop.org/journal/1755-1315

Silva, J. F., Almeida, J. E., Rossetti, R. J. F., \& Coelho, A. L. (2013, May). A serious game for EVAcuation training [Conference paper]. IEEE 2nd International Conference on Serious Games and Applications for Health, Vilamoura, Portugal. http:// dx.doi.org/10.1109/SeGAH.2013.6665302

Slovic, P. (1987). Perception of risk. Science, 236(4799), 280-285.

SouthwickJr,L., \&Butler,R.J.(1985). Firedepartmentdemandand supplyinlargecities. Applied Economics, 17(6), 1043-1064. https://doi.org/10.1080/00036848500000066

Steen-Hansen, A., Storesund, K., \& Sesseng, C. (2021). Learning from fire investigations and research - A Norwegian perspective on moving from a reactive to a proactive fire safety management. Fire Safety Journal, 120, 103047. https://doi.org/ https://doi.org/10.1016/j.firesaf.2020.103047

Stumpf, K., Knuth, D., Kietzmann, D., \& Schmidt, S. (2017). Adoption of fire prevention measures: Predictors in a representative German sample. Safety Science, 94, 94-102. https://doi.org/10.1016/j.ssci.2016.12.023

Sturtevant, V., \& McCaffrey, S. (2006). Encouraging wildland fire preparedness: Lessons learned from three wildfire education programs. In S. M. McCaffr (Ed.), The public and wildland fire management: Social science findings for managers (pp. 125-136). U.S. Department of Agriculture, Forest Service

Sund, B., \& Jaldell, H. (2018). Security officers responding to residential fire alarms: Estimating the effect on survival and property damage. Fire Safety Journal, 97, 1-11. https://doi.org/https://doi.org/10.1016/j.firesaf.2018.01.008

Taylor, J. G., \& Daniel, T. C. (1984). Prescribed fire: Public education and perception. Journal of Forestry, 82(6), 361-365. https://doi.org/10.1093/jof/82.6.361

Useem, M., Cook, J. R., \& Sutton, L. (2005). Developing leaders for decision making under stress: Wildland firefighters in the South Canyon Fire and its aftermath. Academy of Management Learning \& Education, 4(4), 461-485. https://journals.aom.org/ doi/10.5465/amle.2005.19086788\#

Vraćević, N., \& Cvetković, V. (2019). Privantne vojne kompanije u modernom dobu. Vojno delo, 71(2), 42-54. https://doi.org/10.5937/vojdelo1902042V

Warda, L. J., \& Ballesteros, M. F. (2008). Interventions to prevent residential fire injury. In L. Doll, S. Bonzo, D. Sleet, J. Mercy, \& E. N. Haas (Eds.), Handbook of injury and violence prevention (pp. 97-116). Springer.

Xin, J., \& Huang, C. (2013). Fire risk analysis of residential buildings based on scenario clusters and its application in fire risk management. Fire Safety Journal, 62, 72-78. https://doi.org/https://doi.org/10.1016/j.firesaf.2013.09.022 
Xin, J., \& Huang, C. F. (2014). Fire risk assessment of residential buildings based on fire statistics from China. Fire Technology, 50(5), 1147-1161. https://doi.org/10.1007/ s10694-013-0327-8

Xuesong, G., \& Kapucu, N. (2019). Examining stakeholder participation in social stability risk assessment for mega projects using network analysis. International Journal of Disaster Risk Management, 1(1), 1-31. http://dx.doi.org/10.18485/ ijdrm.2019.1.1.1

Zamarreño-Aramendia, G., Cristòfol, F. J., de-San-Eugenio-Vela, J., \& Ginesta, X. (2020). Social-media analysis for disaster prevention: Forest fire in Artenara and Valleseco, Canary Islands. Journal of Open Innovation: Technology, Market, and Complexity, 6(4), 169. https://doi.org/10.3390/joitmc6040169

Zhao, C. M., Lo, S. M., Zhang, S. P., \& Liu, M. (2009). A post-fire survey on the pre-evacuation human behavior. Fire Technology, 45(1), 71-95. https://doi. org/10.1007/s10694-007-0040-6 


\section{APPENDIX}

Questionnaire

\section{General part}

1. Your gender: a) male; b) female.

2. Circle the age group you belong to: a) $18-40$ years; b) $41-60$ years; v) over 60 years.

3. The level of your education is: a) elementary school; b) high school; v) higher school; g) faculty; d) postgraduate studies.

4. What is your marital status: a) single; b) in a relationship; v) engaged; g) married; d) divorced; j) widower.

5. Your work experience in the security service: a) up to 5 years; b) 5-10 years; v) over 10 years.

\section{Questions}

1. Have you ever participated in extinguishing the fire?

$$
\text { Yes No }
$$

2. Do you think that there is a risk of fire in your workplace?

$$
\text { Yes No }
$$

3. Is there a fire extinguisher in your workplace?

$$
\text { Yes No }
$$

4. Did you have the opportunity to use a fire extinguisher?

Yes No

5. Are you familiar with the proper use of fire extinguisher? Yes No

6. Did you have the opportunity to use the fire hydrant grid? Yes No

7. Are you familiar with combustion processes?

Yes No

8. Are you familiar with the methods of extinguishing fire?

Yes No

9. Are you aware of the preventive measures that have been taken at your workplace?

Yes No

10. Are there emergency procedures in your workplace?

$$
\text { Yes No }
$$

11. Are you familiar with the guidelines on how to act in case of activation of the fire alarm?

Yes No

12. Are you familiar with the fire emergency action plan?

Yes No

13. Are you familiar with the evacuation plan?

$$
\text { Yes No }
$$


14. Are the fire emergency evacuation exercises being carried out at your workplace?

Yes No

15. Evaluate the level of preparedness of the facility you are working at.

$$
\begin{array}{lllll}
1 & 2 & 3 & 4 & 5
\end{array}
$$

16. Evaluate the level of your personal preparedness.

$$
\begin{array}{lllll}
1 & 2 & 3 & 4 & 5
\end{array}
$$

17. Evaluate the level of preparedness of the colleagues you work with.

$$
\begin{array}{lllll}
1 & 2 & 3 & 4 & 5
\end{array}
$$

18. Estimate the probability of fire occurrence at your workplace within the next 5 years.

$$
\begin{array}{lllll}
1 & 2 & 3 & 4 & 5
\end{array}
$$

19. In your opinion, what is the most probable consequence of the fire?

1) Material consequences

2) Loss of life

3) Injuries

4) Environmental consequences

5) No consequences

20. In your opinion, what is the correct procedure in case of activation of the fire alarm control panel?

1) Leave the workplace.

2) Wait for the alarm to go off.

3) Read the information on the control panel.

4) Call the fire department immediately.

5) Call the head of the security department.

21. Specify the legal period for retesting fire extinguishers.
1) 3 months
2) 6 months
3) 9 months
4) 12 months
5) Never

22. The fire department's phone number is (write online)

23. Specify the type of fire what can be extinguished with a fire extinguisher.
a) Wildfire
b) Any fire
c) Only fire at the early stages
d) Fire at the oil facility inflamed
e) I am not sure.

24. What would you use to put out the fire on an electrical installation?
1) Powder
2) Foam
3) Water
4) Sand
5) I am not sure. 
25. Did you attend work-life training on safety and health?

Yes No

26. I have a license to assess risk in the protection of persons, property, and business.

Yes No

27. I have a license to perform the basic tasks of a security officer - without weapons.

Yes No

28. I have a license to perform specialist tasks of security officers with weapons. Yes No

29. I have a license to perform technical protection system planning operations. Yes No

30. I have a license to perform technical protection activities.

Yes No

31. I have a certificate of passed exam in the area of fire protection.

Yes No 
